JURNAL KEBIDANAN

Vol 6, No 3, Juli 2020 : 342-348

\title{
PEMBERIAN VITAMIN C DAPAT MENINGKATKAN KADAR HEMOGLOBIN PADA IBU HAMIL ANEMIA
}

\author{
Risma Agusmayanti ${ }^{1}$, Achmad Farich $^{2}$, Anggraini $^{3}$ \\ 1Program Studi DIV Kebidanan Fakultas kedokteran Universitas Malahayati Bandar Lampung \\ email: rismaagusmayanti@gmail.com \\ 2Universitas Malahayati Bandar Lampung \\ email: farichrich@malahayati.co.id \\ ${ }^{3}$ Program Studi DIII Kebidanan Universitas Malahayati Bandar Lampung \\ email: albarr_arsenio@yahoo.com
}

\begin{abstract}
Background: anemia in pregnancy is anemia due to iron deficiency, and is a type of anemia which is relatively easy treatment, even cheap. Efforts to overcome iron nutritional anemia in pregnant women are done through increasing the coverage of iron tablet supplementation, Vitamin C has unstable properties in alkaline solutions, stable in dry conditions and in acidic solutions, and as an iron catalyst so that helps absorption. Preliminary survey conducted by researchers in January 2019 from observations from 3 posyandu in the ANC book found that 65 pregnant women consisted of Posyandu Strawbery 1, namely TM 2 (4 people), TM III (8 people), in Posyandu Strawbery II TM 2 ( 8 people), TM III (23 people). And in the Strawbery III posyandu namely TM 2 (7 people), TM III (15 people).

Purpose: of this study is to know the effect of Vit $\mathrm{C}$ on hemoglobin levels in pregnant women with anemia in the village of Ringin Sari Banjar Margo, Tuba Tulang Bawang Regency in 2019.

Methods: quantitative with pre-experimental action, One group pretest - posttest design. The population in this study were all pregnant women with anemia as many as 65 respondents. A sample of 30 people, the sampling technique used was purposive sampling. Data collection using observation sheets, how to administer Vit $C$ was given 1 day $50 \mathrm{mg}$ to be consumed for 14 days $1 \times 50 \mathrm{mg} /$ day taken after lunch together with $\mathrm{FE}$ tablets and the data analysis used was the T-dependent test.

Results: of the study are known to be the average value of hemoglobin levels before administration of Vit C 8,980 and standard deviation. The average value of hemoglobin levels after administration of Vit $C$ was 12,190 and a standard deviation of 8397.

Conclution: There Is An Effect Of Giving Vit C On Increasing Hb Levels In Pregnant Women (p value $0,0003<0.05$ ). Suggestions For pregnant women can consume Fe + vit $C$ tablets regularly in order to prevent anemia and to consume foods that contain vitamin C.

Suggestion Pregnant women are expected to routinely take Vit $C$ together with FE tablets at 13 weeks to 40 weeks' gestation, as recommended, so that at the time of delivery the mother does not experience anemia.
\end{abstract}

Keywords: Anemia, vit C, Hemoglobin

\section{ABSTRAK}

Latar belakang : anemia pada kehamilan adalah anemia karena kekurangan zat besi, dan merupakan jenis anemia yang pengobatannya relatif mudah, bahkan murah. Upaya penanggulangan anemia gizi besi pada ibu hamil dilakukan melalui peningkatan cakupan suplementasi tablet besi, Vitamin C memiliki sifat yang labil dalam larutan alkali, stabil dalam kondisi kering dan dalam larutan asam, dan sebagai katalisator besi sehingga membantu penyerapan. Survey pendahuluan yang peneliti lakukan pada januari Tahun 2019 dari hasil observasi dari 3 posyandu pada buku ANC diketahui 65 ibu hamil yang terdiri dari posyandu Strawbery 1 yaitu TM 2 (4 orang), TM III (8 orang), di posyandu Strawbery II TM 2 (8 orang), TM III (23 orang). Dan di posyandu Strawbery III yaitu TM 2 (7 orang), TM III (15 orang).

Tujuan penelitian :diketahui Pengaruh Vit C terhadap Kadar Hemoglobin Pada Ibu Hamil Anemia didesa Ringin Sari Banjar Margo Kabupaten Tuba Tulang Bawang Tahun 2019.

Metode: kuantitatif dengan tindakan pra eksperimen, rancangan One group pretest - posttest design. Populasi dalam penelitian ini adalah seluruh ibu hamil yang mengalami anemia sebanyak 65 responden. Sampel 30 orang, Teknik sampling yang digunakan purposive sampling. Pengumpulan data dengan menggunakan lembar observasi, cara pemberian Vit $\mathrm{C}$ diberikan 1 hari $50 \mathrm{mg}$ untuk dikosumsi selama 14 hari $1 \times 50 \mathrm{mg} / \mathrm{hari}$ 
diminum setelah makan siang bersamaan dengan tablet FE dan analisa data yang digunakan adalah uji $T$ dependent.

Hasil: diketahui Nilai rata-rata kadar hemoglobin sebelum pemberian Vit C 8.980 dan standar deviasi .8277. Nilai rata-rata kadar hemoglobin sesudah pemberian Vit C 12.190 dan standar deviasi .8397.

Kesimpulan: Ada Pengaruh Pemberian Vit C Terhadap Peningkatan Kadar Hb Pada Ibu Hamil ( $\mathrm{p}$ value $0,0003<0,05$ ). Saran bagi ibu hamil dapat mengkonsumsi tablet $\mathrm{Fe}+$ vit $\mathrm{C}$ secara rutin guna pencegahan terjadinya anemia serta mengkonsumsi makanan yang mengandung vitamin $\mathrm{C}$.

Saran Bagi lbu Hamil diharapkan untuk rutin mengkonsumsi Vit $C$ bersamaan tablet FE pada usia kehamilan 13 minggu hingga 40 minggu, sesuai dengan anjuran, agar pada waktu persalinan ibu tidak mengalami anemia

Kata Kunci : Anemia, vit C, kadar hemoglobin

\section{PENDAHULUAN}

Menurut WHO (2008), prevalensi anemia pada ibu hamil diperkirakan di Asia sebesar 48,2 \%, Afrika 57,1 \%, Amerika 24,1\%, dan Eropa 25,1\%. Berdasarkan riskesdas 2013 terdapat $37,1 \%$ ibu hamil anemia, yaitu ibu hamil dengan kadar $\mathrm{Hb}$ kurang dari 11,0 gram/dl, dengan proporsi yang hampir sama antara di kawasan perkotaan $(36,4 \%)$ dan pedesaan (37,8\%) (Riskesdas, 2013). Meskipun pemerintah sudah melakukan program penanggulangan anemia pada ibu hamil yaitu dengan memberikan 90 tablet Fe kepada ibu hamil selama periode kehamilan dengan tujuan menurunkan angka anemia ibu hamil, tetapi kejadian anemia masih tinggi. (Kementerian Kesehatan RI, 2013).

Berdasarkan data WHO 2015 Anemia merupakan salah satu faktor penyebab tidak langsung kematian ibu hamil. Berdasarkan WHO Prevalensi anemia ibu hamil di dunia berkisar ratarata $14 \%$, di negara industri $56 \%$ dan di negara berkembang antara 35\%-75\%. Secara gelobal, sebesar $52 \%$ wanita hamil di negara-negara berkembang mengalami anemia. Angka ini lebih besar di bandingkan dengan angka anemia pada wanita hamil di negara-negara industri yang hanya sebesar $20 \%$. Negara dengan prevalensi anemia pada wanita hamil tertinggi adalah india ( $88 \%$ ), di ikuti oleh Afrika (50\%), dan karibia (30\%). Berdasarkan WHO tahun 2008 prevalensi anemia ibu hamil di asia tenggara 48,2\%. Menurut encyclopedis of national Indonesia berada $\mathrm{di}$ peringkat ke-58 dengan prevalensi anemia pada ibu hamil sebanyak 44,3\% (WHO, 2015).

Berdasarkan data Riskesdas 2018, angka anemia ibu hamil sebanyak 48,9\%, anemia berdasarkan umur 15-24 tahun sebanyak $84,6 \%$, 25-34 tahun sebanyak 33,7\%, 35-44 tahun sebanyak $33,6 \%$ dan umur $45-55$ tahun sebanyak $24 \%$. Sedangkan ibu hamil yang mendapat tablet tambah darah sebesar $73,2 \%$ dan yang tidak mendapatkan tablet tambah darah sebesar $26,8 \%$ (Riskesdas, 2018).

Provinsi Lampung tercatat sebagai peringkat utama di wilayah Sumatra untuk jumlah penderita anemia. Tingginya jumlah anemia ibu hamil di provinsi lampung yaitu sebanyak $69,7 \%$ angka itu lebih tinggi dari angka anemia gizi nasional yaitu sebanyak 63\% (Dinas Kesehatan Provinsi Lampung, 2010) anemia adalah suatu kondisi medis dimana jumlah sel darah merah atau hemoglobin kurang dari normal. Kadar hemoglobin normal umumnya berbeda pada laki-laki dan perempuan. Untuk pria, anemia biasanya didefinisikan sebagai kadar hemoglobin kurang kurang dari 13,5 gram/ $100 \mathrm{ml}$ dan pada wanita sebagai hemoglobin kurang dari 12,0 gram $/ 100 \mathrm{ml}$ (Proverawati, 2011).

Berdasarkan Profil Kesehatan Provinsi Lampung tahun 2017 menunjukan data bahwa dari 24.733 ibu hamil yang terdapat di Provinsi Lampung sebanyak 21.771 (88\%) mendapat Fe1 dan 21259 $(85,9 \%)$ mendapat $\mathrm{Fe} 3$ dan jumlah ibu hamil yang diperiksa $\mathrm{Hb}$ berjumlah 23.160 jiwa atau sekitar $93 \%$. Ibu hamil yang mengalami anemia berjumlah $8.435(36,4 \%)$ dengan kadar $\mathrm{Hb}$ 8-11 gr/dl dan 810 ibu hamil atau $(3,4 \%)$ dengan kadar $\mathrm{Hb}<8 \mathrm{gr} / \mathrm{dl}$ (Profil Kesehatan Provinsi Lampung, 2017).

Berdasarkan data Dinas Kesehatan Kabupaten Tulang Bawang, 2018 data anemia ibu hamil di Tulang Bawang pada tahun 2016 terdapat 293 orang ibu hamil dengan anemia dan mengalami peningkatan pada tahun 2017 sebesar 311 orang ibu hamil dengan anemia, dan prevalensi tertinggi terdapat pada puskesmas Banjar Margo sebesar 78 orang $(21,1 \%)$ tahun 2016 sedangkan pada tahun 2017 mengalami kenaikan sebesar 94 orang $(26,3 \%)$ (Dinas Kesehatan Kabupaten Tulang Bawang, 2017).

Menurut Dinas Kesehatan Tulang Bawang, 2016 data anemia ibu hamil di Puskesmas banjar margo pada tahun 2016 sebesar 78 orang $(22,1 \%)$, 
dan mengalami peningkatan pada tahun 2017 sebesar sebesar 98 orang $(26,3 \%)$,

Faktor kematian maternal dapat di tinjau dari usia dan paritas, kematian ibu dapat dikarenakan karena hemoragi, 15\% karena sepsis, $12 \%$ karena gangguan hipertensi kehamilan, $8 \%$ karena persalinan macet, dan hamper $13 \%$ karena abortus. Sekitar 20\% wanita meninggal akibat suatu penyakit yang diperberat dengan kehamilan seperti anemia, hioertensi, hepatitis TBC dan penyakit jantung (Kusmiran, 2012).

Anemia pada kehamilan adalah anemia karena kekurangan zat besi, dan memrupakan jenis anemia yang pengobatannya realtif mudah, bahkan murah. Anemia pada kehamilan merupakan masalah nasional karena mencerminkan nilai kesejahteraan sosial ekonomi masyarakat, dan pengaruhnya sangat kasar terhadap kualitas sumber daya manusia. (Manuaba, 2010).

Anemia merupakan salah satu faktor penyebab tidak langsung kematian ibu hamil. Berdasarkan laporan World Health Organization (WHO) tahun 2008, prevalensi anemia pada ibu hamil di Asia Tenggara 48,2\%. Kebanyakan anemia yang diderita masyarakat adalah karena kekurangan zat besi yang dapat diatasi melalui pemberian zat besi secara teratur dan peningkatan gizi. Selain itu di daerah pedesaan banyak dijumpai ibu hamil dengan malnutrisi atau kekurangan gizi; kehamilan dan persalinan dengan jarak yang berdekatan; dan ibu hamil dengan pendidikan dan tingakt sosial ekonomi rendah (Manuaba, 2010).

Gizi sangat diperlukan untuk kesehatan ibu, kualitas kehamilan dan keselamatan bayi. Kebutuhan ibu selama kehamilan ialah $800 \mathrm{mg}$ besi, diantaranya $300 \mathrm{mg}$ untuk janin plasenta dan $500 \mathrm{mg}$ untuk pertambahan eritrosit ibu. Dengan demikian ibu membutuhkan tambahan sekitar 2-3 $\mathrm{mg}$ besi/ hari. Ibu Hamil memerlukan banyak makanan tambahan diantaranya yaitu protein, vitamin $C$ dan zat-zat besi dibanding wanita biasa. Apabila ibu hamil sampai kekurangan gizi terutama zat besi dan asam folat maka dapat terjadi anemia defisiensi besi karena dalam kehamilan keperluan zat-zat makanan bertambah dan terjadi pula perubahan-perubahan dalam darah dan sum-sum tulang. Selain itu kebutuhan zat gizi selama hamil diperlukan untuk pertumbuhan janin, plasenta dan jaringan lainnya (Muhilal, 2002).

Prevalensi anemia di Indonesia $40-50 \%$ dan anemia defisiasi besi menempati peringkat pertama, apabila prevalensi kadar hemoglobin 2 standar deviasi di bawah rata-rata lebih dari $5 \%$ anemia defisiasi besi dapat dikatakan sebagai masalah kesehatan masyarakat. Anemia ibu hamil harus dapat kita tangani, tidak hanya peran pemerintah, tetapi peran orang terdekat seperti keluarga, dan tenaga kesehatan, ikut peran serta untuk menangani anemia ibu hamil, kecukupan gizi pada ibu hamil juga harus di perhatikan karena makanan ibu hamil di butuhkan untuk dirinya dan janin yang di kandung, seperti makanan yang cukup mengandung karbohidrat, dan lemak sebagai sumber tenaga, protein sebagai zat sumber pembangun, serta vitamin dan mineral sebagai zat pengatur, diharapkan tidak ada kesulitan dalam konsumsi makanan setiap harinya.

Berdasarkan permasalahan yang ada yaitu, masih tingginya angka kejadian anemia ibu hamil didesa Ringin Sari Banjar Margo yaitu tahun 2017 sebesar 183 (19\%) sedangkan tahun 2018 sebesar $234(25 \%)$, yang menyebabkan ibu menjadi kurus, lemah, pucat, gigi rusak, jika makanan ibu kurang maka ibu akan mengalami anemia dan tumbuh kembang janin akan terganggu, terlebih jika gizi ibu saat kehamilan buruk. Akibat anemia dapat terjadi gangguan dalam bentuk: abortus, kematian intrauterine, persalinan prematuritas tinggi, berat badan lahir rendah, kelahiran dengan anemia, dapat terjadi cacat bawaan, bayi mudah mendapat infeksi sampai kematian perinatal, dan inteligensi rendah.

\section{METODOLOGI PENELITIAN}

Jenis penelitian yang digunakan dalam penelitian ini adalah kuantitatif dengan pendekatan quasi eksperimen dengan rancangan One group pretest - posttest design. Tempat penelitian ini dilaksanakan didesa Ringin Sari Banjar Margo Kabupaten Tuba Tulang Bawang Waktu penelitian telah dilaksanakan pada bulan januari - juli 2019

Populasi dalam penelitian ini adalah Seluruh ibu hamil trimester II dan III yang mengalami anemia sebanyak 65 responden pada bulan Januari 2019 dengan jumlah sampel 30 orang. Pengambilan sample penelitian ini dilakukan dengan menggunakan teknik purposve sampling yaitu mengambil sampel berdasarkan kriteria yang peneliti tentukan(Notoatmodjo, 2018).

\section{HASIL PENELITIAN}

Tabel 1.

Karakteristik responden berdasarkan usia lbu, usia kehamilan dan paritas

\begin{tabular}{lcc}
\hline \multicolumn{1}{c}{ Variabel } & Frekuensi & $\%$ \\
\hline Usia Ibu & & \\
20-25 Tahun & 15 & $50.0 \%$ \\
26-30 Tahun & 11 & $36.7 \%$ \\
31-35 Tahun & 4 & $13.3 \%$
\end{tabular}


Usia kehamilan

\begin{tabular}{lcc}
$20-25$ minggu & 9 & $30.0 \%$ \\
$26-30$ minggu & 15 & $50.0 \%$ \\
$31-35$ minggu & 6 & $20.0 \%$ \\
Paritas & & \\
Primipara & 5 & $16.7 \%$ \\
Multipara & 25 & $83.3 \%$ \\
Total & 30 & $100 \%$ \\
\hline
\end{tabular}

Berdasarkan tabel 1 dapat diketahui bahwa sebagian besar responden yaitu usia 20-25 tahun sebanyak 15 orang $(50 \%)$, usia $26-30$ tahun sebanyak 11 orang $(36,7 \%)$ dan usia 31-35 tahun sebanyak 4 orang $(13,3 \%)$, Karakteristik usia kehamilan sebagian besar responden yaitu dengan usia kehamilan 21-25 minggu sebanyak 9 orang (30\%), usia 26-30 minggu sebanyak 15 orang (50.0 $\%$ ) dan usia 31-35 minggu sebanyak 6 orang (20\%). Sedangkan karakteristik responden berdasarkan paritas dapat diketahui bahwa sebagian besar responden yaitu dengan paritas primipara sebanyak 5 orang $(16.7 \%)$, multipara sebanyak 25 orang $(83.3 \%)$.

Berdasarkan tabel 2 Hasil analisis dapat dilihat dari 30 responden, diketahui bahwa pemberian Vit $\mathrm{C}$ terhadap kenaikan kadar hemoglobin pada ibu hamil nilai minimal (nilai kadar hemoglobin terendah) 7.5 dan nilai maksimal (nilai kadar hemoglobin tertinggi) 10.4 dengan nilai rata- rata sebelum pemberian Vit C 8.980 dan standar deviasi 0.8277 .

Tabel 2.

Distribusi frekuensi rata-rata kadar hb sebelum mengkonsumsi Vit $\mathrm{C}$ pada Ibu Hamil

\begin{tabular}{lcccc}
\hline \multicolumn{1}{|c}{ Variabel } & $\mathrm{N}$ & Mean & Min-Mak & SD \\
\hline $\begin{array}{l}\text { Sebelum } \\
\text { pemberian } \\
\text { Vit C }\end{array}$ & 30 & 8.980 & $7.5-10.4$ & 0.8277 \\
\hline
\end{tabular}

Tabel 3.

Distribusi frekuensi rata-rata kadar hb setelah mengkonsumsi Vit $\mathrm{C}$ pada Ibu Hamil

\begin{tabular}{lcccc}
\hline Variabel & $\mathrm{N}$ & Mean & Min-Mak & $\mathrm{SD}$ \\
\hline $\begin{array}{l}\text { Sesudah } \\
\text { pemberian }\end{array}$ & 30 & 12.190 & $11,0-13,8$ & .8397 \\
Vit C & & & \\
\hline
\end{tabular}

Berdasarkan tabel 3 Hasil analisis dapat dilihat dari 18 responden, diketahui bahwa pemberian Vit $\mathrm{C}$ terhadap kenaikan kadar hemoglobin pada ibu hamil nilai minimal (nilai kadar hemoglobin terendah) 11,0 dan nilai maksimal (nilai kadar hemoglobin tertinggi) 13,8 dengan nilai ratarata sesudah pemberian Vit C 12.190 dan standar deviasi .8397.

Tabel 4.

Pengaruh Pemberian Vit C Terhadap Kadar Hemoglobin Pada Ibu Hamil Anemia di desa Ringin Sari Banjar Margo Kabupaten Tulang Bawang Tahun 2019

\begin{tabular}{ccccccc}
\hline Variabel & $\begin{array}{c}\text { Mean(Nilai } \\
\text { Rata-Rata) }\end{array}$ & $\begin{array}{c}\text { Selisih } \\
\text { skor }\end{array}$ & $\begin{array}{c}\text { SD } \\
\text { (Standar Deviasi) }\end{array}$ & P (Value) & $\begin{array}{c}\mathrm{N} \text { (Jumlah } \\
\text { Sampel) }\end{array}$ & $\begin{array}{c}\text { Cl 95\% } \\
\text { (low-up) }\end{array}$ \\
\hline Sebelum pemberian Vit C & 8.980 & \multirow{2}{*}{3.210} & .8277 & \multirow{2}{*}{0,0003} & 30 & $3.6897-$ \\
Sesudah pemberian Vit C & 12.190 & \multirow{2}{*}{.8397} & & 2.7303 \\
\hline
\end{tabular}

Berdasarkan tabel 4 diatas, dapat dilihat nilai rata-rata, standar deviasi dan standar error untuk masing-masing variabel. Nilai rata-rata kadar hemoglobin sebelum pemberian Vit $\mathrm{C}$ adalah 8.980 , sedangkan nilai rata-rata kadar hemoglobin sesudah pemberian Vit $\mathrm{C}$ adalah 12.190. Hasil uji statistik yang dilihat dari nilai Sig. (2-tailed) pada tabel independent sample test adalah 0,0003 < 0,05 , maka Ho ditolak. Dapat disimpulkan bahwa ada pengaruh pemberian Vit $C$ terhadap peningkatan kadar hb pada ibu hamil anemia.

\section{PEMBAHASAN}

Rerata Kadar Hemoglobin Ibu Hamil Sebelum diberi Vit C

Berdasarkan tabel. 2 Hasil analisis dapat dilihat dari 30 responden, diketahui bahwa pemberian Vit $\mathrm{C}$ terhadap kenaikan kadar hemoglobin pada ibu hamil nilai minimal (nilai kadar hemoglobin terendah) 7.5 dan nilai maksimal (nilai kadar hemoglobin tertinggi) 10,4 dengan nilai ratarata sebelum pemberian Vit C 8.980 dan standar deviasi .827

Anemia defisiensi pada wanita hamil merupakan problema kesehatan yang dialami oleh wanita diseluruh dunia terutama dinegara perkembangan (Indonesia). WHO melaporkan bhawa prevalensi wanita hamil yang mengalami 
defisiensi sekitar $35-75 \%$ serta semakin meningkat seiring dengan bertambah usia. (Yeyeh, 2010).

Ibu hamil memerlukan asupan gizi yang cukup untuk dirinya dan bayi yang di kandung, sehingga kebutuhan gizinya lebih tinggi dibandingkan saat belum hamil.lbu hamil harus mengkonsumsi makanan seperti hari sesuai dengan kebutuhan tubuhnya (Winarsih, 2018).

Wanita hamil membutuhkan setidaknya 285 Kkal tambahan energi dari kebutuhan wanita dewasa yang tidak hamil sebesar 1900-2400 Kkal/hari. Untuk itu, perlu pasokan energi dari makanan-makanan yang di konsumsi (Fatonah 2016).

Menurut pendapat peneliti, ibu hamil sebelum diberikan vit $\mathrm{c}$ mengalami anamia ringan dan sedang, diketahui kadar hemoglobin ibu ringan yaitu 10,4 $\mathrm{gr} / \mathrm{dl}$ dan kadar hemoglobin ibu sedang yaitu $7,5 \mathrm{gr} / \mathrm{dl}$ dikarenakan ibu mengalami paritas lebih dari 1 yaitu multipara. Banyak faktor yang dapat menyebabkan timbulnya anemia defisiensi besi, antara lain kurangnya asupan zat besi dan protein dari makanan, adanya gangguan absorpsi di usus, perdarahan akut maupun kronis, dan meningkatnya kebutuhan zat besi seperti pada wanita hamil, masa pertumbuhan dan masa penyembuhan dari penyakit.

\section{Rerata Kadar Hemoglobin Ibu Hamil sesudah diberi Vit C}

Berdasarkan tabel. 3 Hasil analisis dapat dilihat dari 30 responden, diketahui bahwa pemberian Vit $\mathrm{C}$ terhadap kenaikan kadar hemoglobin pada ibu hamil nilai minimal (nilai kadar hemoglobin terendah) 11,0 dan nilai maksimal (nilai kadar hemoglobin tertinggi) 13,8 dengan nilai ratarata sesudah pemberian Vit C 12.190 dan standar deviasi 0.8397 .

Faktor-faktor yang dapat menyebabkan anemia antara lain kehilangan darah karena pendarahan akut/kronis (seperti riwayat persalinan dan haid), kerusakan sel darah merah, produksi sel darah merah yang tidak cukup banyak, kurang gizi (malnutrisi), kurang zat besi dalam pola makan, gangguan penyerapan (malabsorbsi), serta penyakit-penyakit kronis, seperi TB paru, cacing usus, dan malaria (Fatonah, 2016).

Zat besi merupakan mikroelemen yang esensial bagi tubuh. Zat ini terutama diperlukan dalam hemopoboesis (pembentukan darah) yaitu sintesis hemoglobin $(\mathrm{Hb})$. Hemoglobin $(\mathrm{Hb})$ yaitu suatu oksigen yang mengantarkan eritrosit berfungsi penting bagi tubuh. Hemoglobin terdiri dari Fe (zat besi), protoporfirin, dan globin (1/3 berat $\mathrm{Hb}$ terdiri dari Fe). (Depkes RI, 2008).
Penambahan zat besi selama kehamilan kira-kira 1000 mg, karena mutlak dibutuhkan untuk janin, plasenta dan penambahan volume darah ibu. Sebagian dari peningkatan ini dapat dipenuhi oleh simpanan zat besi dan peningkatan adaptif persentase zat besi yang diserap. Tetapi bila simpanan zat besi rendah atau tidak ada sama sekali dan zat besi yang diserap dari makanan sangat sedikit maka, diperlukan suplemen preparat besi. (Depkes RI, 2007).

Berdasarkan hasil penelitian peneliti berpendapat bahwa ibu hamil setelah mengkonsumsi Vit C Terhadap Peningkatan Kadar $\mathrm{Hb}$ Pada Ibu Hamil kadar hemoglobin naik nilai ratarata kadar hemoglobin sesudah pemberian Vit $\mathrm{C}$ adalah 12.190. Vitamin $C$ berfungsi untuk mensintesis kolagen, absopsi dari metabolisme besi, absopsi kalsium, mencegah infeksi, serta meningkatkan daya tahan terhadap infeksi. Vitamin C juga membantu penyerapan zat besi di dalam tubuh, sehingga dapat meningkatkan kadar hemoglobin pada ibu hamil.

\section{Pengaruh Vit $\mathbf{C}$ terhadap kadar hemoglobin Pada Ibu Hamil anemia}

Berdasarkan tabel 4 diatas, dapat dilihat nilai rata-rata, standar deviasi dan standar error untuk masing-masing variabel. Nilai rata-rata kadar hemoglobin sebelum pemberian Vit $\mathrm{C}$ adalah 8.980, sedangkan nilai rata-rata kadar hemoglobin sesudah pemberian Vit $C$ adalah 12.190. Hasil uji statistik yang dilihat dari nilai Sig. (2-tailed) pada tabel independent sample test adalah 0,0003 < 0,05 , maka Ho ditolak. Dapat disimpulkan bahwa ada pengaruh pemberian Vit $C$ terhadap peningkatan kadar hb pada ibu hamil anemia.

Asupan zat besi di perlukan setiap hari untuk mengganti zat besi yang hilang melalui feses, urin, dan kulit. Kehilangan basal ini kira-kira $14 \mathrm{ug} / \mathrm{kg}$ atau $\mathrm{bb} /$ hari atau hamir sama dengan $0,9 \mathrm{mg}$ zat besi pada laki-laki dewasa dan $0,8 \mathrm{mg}$ bagi permpuan dewasa. Zat besi dalam makanan dapat berbentuk home dan nonheme (Fatonah, 2016).

Proses pembentukan eritrosit disebut eritropoisis, dalam tubuh terdapat 3-5 atau 2,5-4 gram $\mathrm{Fe}, 30-40 \%$ nya dalam bentuk cadangan besi. Distribusi $\mathrm{Fe} 70 \%$ (2- 2,5 g) terdapat dalam $\mathrm{Hb}$. $26 \%$ sebagai cadangan besi dalam liver, limpa dan tulang. Dalam makanan, besi sebagai ikatan organik yaitu garam Fe (Ferro dan Ferri sulfat). Bentuk ferro lebih mudah diserap. Di dalam tubuh Fe berikatan dengan protein (bentuk ferro maupun ferri). Bentuk aktif umumnya berupa bentuk ferro. Terdapat 2 bentuk besi yaitu Besi Heme dan non heme, pada daging merah terdapat $40 \%$ besi heme 
dan $60 \%$ besi non heme. Banyak berasal dari hemoglobin dan myoglobin dalam daging, unggas dan ikan. Hanya terdapat 5-10\% dari makanan yang dikonsumsi. Penyerapan 2-3x lebih mudah, relative tidak banyak dipengaruhi oleh factor lain dalam makanan. Kebanyakan besi yang ada di makanan adalah besi non heme. Besi non heme ini biasanya didapati pada sayuran dan buah-buahan. Sekitar $25-35 \%$ besi heme yang diabsorbsi, sedangkan pada besi non heme mengalami penurunan $3 \%$ dari besi heme untuk penyerapannya. Perbedaan jumlah yang diabsorbsi ini sangat penting. Besi heme hanya ada pada daging hewan. Sehingga bagi vegetarian harus waspada akan jumlah besi non heme yang hanya sedikit diabsorbsi. Penyerapan hanya 5\% (Anderson, 2010).

Fungsi usus halus adalah menyerap nutrisi, setiap bagian usus halus menyerap nutrisi tertentu seperti bagian usus dua belas jari yang menyerap mineral seperti zat besi dan kalsium. Proses Penyerapan $\mathrm{Fe}$ dalam tubuh berlangsung di lambung, usus 12 jari dan usus halus pada empedu sehingga menjadi asam yang dapat menghasilkan $\mathrm{Fe}$, sehingga vit $\mathrm{C}$ yang terbentuk dari asam menyebabkan penyerapan $\mathrm{FE}$.

Penelitian Anita (2016) Efektivitas Vitamin C Terhadap Kenaikan Kadar Hb Pada Ibu Hamil Di Kecamatan Pontianak Timur asil penelitian didapatkan ada peningkatan yang signifikan dari awal dan akhir tes (1,09 gr / dl). Di sisi lain, tingkat hemoglobin rata-rata kelompok kontrol pada awal tes adalah 10,17 gr / dl, lebih rendah dari akhir uji $(10,79 \mathrm{gr} / \mathrm{dl})$. Hasilnya menunjukkan bahwa ada peningkatan yang signifikan dari awal dan akhir uji hemoglobin $(0.63 \mathrm{gr} / \mathrm{dl})$. Hasil penelitian menunjukkan bahwa tablet penambah darah dan tambahan vitamin $\mathrm{C}$ menunjukkan hasil yang signifikan dalam meningkatkan kadar hemoglobin pada wanita hamil yang mengonsumsi tablet penambah darah.

Berdasarkan hasil penelitian peneliti berasumsi bahwa ada perbedaan kenaikan kadar hemoglobin pada ibu hamil sebelum dan sesudah mengkonsumsi Vit $\mathrm{C}$ angka kenaikan kadar hemoglobin pada ibu hamil terendah yaitu 0.8 dan 0.9 disebabkan karena asupan nutrisi yang tidak cukup, bertambahnya zat gizi yang hilang, dan meningkatnya kebutuhan nutrisi ibu selama masa hamil. Selain itu ibu hamil yang sudah mempunyai dua anak dan terjadi kehamilan lagi sehingga kesehatannya akan menurun, sering mengalami kurang darah (anemia) yang merupakan faktor internal yang memengaruhi ibu hamil. Sedangkan pemberian sebelum dan sesudah mengkonsumsi Vit $\mathrm{C}$ terhadap kenaikan kadar hemoglobin pada ibu hamil tertinggi yaitu 5.0 dan 5.5 disebabkan karena ibu sering mengkonsumsi makanan yang mengandung nilai gizi bermutu tinggi meskipun tidak berarti makanan yang mahal harganya, ibu hamil teratur mengkonsumsi makanan yang mengandung protein, zat besi, dan minum cukup cairan (menu seimbang). Selain itu faktor tingginya angka kenaikan kadar hemoglobin disebabkan oleh cukupnya waktu untuk beristirahat, kesadaran terhadap asupan gizi yang dikonsumsi sehingga dapat mempercepat kenaikan kadar hemoglobin ibu hamil disertai dengan mengkonsumsi vit $\mathrm{C}$.

\section{KESIMPULAN}

Dari hasil penelitian dapat disimpulkan bahwa Ada Pengaruh Pemberian Vit $C$ Terhadap Peningkatan Kadar Hb Pada lbu Hamil ( $p$ value $0,0003<0,05)$.

\section{SARAN}

Bagi Ibu Hamil diharapkan untuk rutin mengkonsumsi Vit $\mathrm{C}$ bersamaan tablet FE pada usia kehamilan 13 minggu hingga 40 minggu, sesuai dengan anjuran, agar pada waktu persalinan ibu tidak mengalami anemia.Bagi Tempat Penelitian dapat dijadikan penyuluhan untuk tindakan menaikan kadar hemoglobin dan salah satunya dengan menambahkan Vit $C$ terhadap ibu hamil dengan pemantauan HB secara berkala. Bagi Peneliti Selanjutnya Hasil penelitian ini diharapkan untuk dapat melakukan lanjutan dengan membandingkan efektifitas fe dalam menaikkan kadar HB pada ibu primigravida dan multigravida dan membandingkan Trimester I-III dengan menambahkan jumlah sampel yang lebih banyak lagi.

\section{DAFTAR PUSTAKA}

Almatsier, S. (2004). Prinsip Dasar Ilmu Gizi, Cetakan Keempat. PT. Gramedia Pustaka Utama, Jakarta.

Hinderaker, S. G., Olsen, B. E., Lie, R. T., Bergsjø, P. B., Gasheka, P., Bondevik, G. T., ... \& Kvåle, G. (2002). Anemia in pregnancy in rural Tanzania: associations with micronutrients status and infections. European journal of clinical nutrition, 56(3), 192-199.

Kemenkes, R. I. (2016). Pedoman Pencegahan dan Penanggulangan Anemia Pada Remaja Putri dan Wanita Usia Subur (WUS). Direktorat Gizi Masyarakat Direktorat Jenderal Kesehatan Masyarakat Kementerian Kesehatan RI. 
Kementerian Kesehatan RI, 2013.Prevalensi Anemia Pada Ibu Hamil

Notoatmodjo, S. (2012). Metodologi penelitian kesehatan (Cetakan VI). Jakarta: Penerbit PT. Rineka Cipta.

Proverawati, A. (2011). Anemia dan Anemia kehamilan. Yogyakarta: Nuha Medika, 136137.
Seri Luh, 2018. Buku saku anemia defisiensi besi masa prahamil \& hamil. Jakarta: EGC

Siti, F. (2016). Gizi dan Kesehatan Untuk Ibu Hamil. Sulistyawati, A. (2011). Salemba Medika: Asuhan Kebidanan Pada Masa Kehamilan.

Walyani, E. S. (2015). Asuhan kebidanan pada kehamilan. Yogyakarta: Pustaka.

Winarsih, 2018. Pengantar ilmu gizi dalam kebidanan. Yogyakarta: Pustaka baru press 